\title{
PENERAPAN TEKNOLOGI TEPAT GUNA UNTUK MENINGKATKAN KAPASITAS PRODUKSI KUE KARAH PADA UMKM DI DESA LANGUNG KECAMATAN MEUREUBO
}

\section{APPLICATION OF APPROPRIATE TECHNOLOGY TO IMPROVE PRODUCTION CAPACITY OF KUE KARAH OF THE UMKM IN LANGUNG VILLAGE MEUREUBO SUB-DISTRICT}

\author{
Fitriadi $^{1^{\star}}$, Muzakir ${ }^{1}$, Arie Saputra ${ }^{1}$, Nissa Prasanti ${ }^{1}$, Khairul Hadi ${ }^{1}$, ling Pamungkas ${ }^{1}$, Heri \\ ${ }^{1}$ Prodi Teknik Industri Fakultas Teknik Universitas Teuku Umar \\ *Korespondensi: fitriadi@utu.ac.id /Mobile Phone :+68116830574
}

\begin{abstract}
ABSTRAK
Kue Karah adalah kue tradisional yang sudah menjadi bagian khazanah budaya masyarakat Aceh sejak masa silam. Di kabupaten Aceh Barat, sentra produksi Kue Karah ada di Kecamatan Meureubo terutama di Desa Langung. Permasalahan mitra dalam produksi kue karah adalah proses pembuatan kue karah tersebut dengan cara tradisional. Pada proses pembuatan pekerja mengalami risiko kelelahan dan muskuloskeletal disorder yang disebabkan oleh paparan panas alat produksi. Selain itu, kualitas produk yang dihasilkan tidak terstandarisasi dan manajemen organisasi dan keuangan masih berbasis keluarga. Untuk alasan ini, perlu menerapkan teknologi yang tepat untuk mengatasi kelemahan ini. Program pengabdian masyarakat ini adalah program kemitraan komunitas antara universitas dan pembuat UMKM Kue Karah. Program ini tidak hanya menawarkan pemecahan masalah mengenai penggunaan pembuat Kue Karah, tetapi juga transfer teknologi dalam bentuk pembuat Kue Karah untuk meningkatkan kualitas produk Kue Karah dan meningkatkan volume produksi. Selain itu, program pengabdian ini juga memberikan pelatihan dan pendampingan manajemen organisasi dan keuangan. Dengan demikian program ini memiliki nilai yang komprehensif, bermakna, lengkap dan berkelanjutan.
\end{abstract}

Kata Kunci: Kue Karah; Kue Tradisional; Risiko Kelelahan; Teknologi Tepat Guna

\begin{abstract}
Kue Karah is a traditional cake that has been part of the cultural richness of the Acehnese people for a long time. In West Aceh district, the center of Kue Karah production is in Meureubo District, especially in Langung Village. The problem of partners in making Kue Karah is the process of making karah cakes in the traditional way. In the manufacturing process workers experience the risk of fatigue, and musculoskeletal disorders caused by exposure to heat production equipment. In addition, the quality of products produced is not standardized and organizational and financial management is still family based. For this reason, it is necessary to apply the right technology to overcome this weakness. This community service program is a community partnership program between the university and UMKM makers Kue Karah. This program not only offers problem solving regarding the use of Kue Karah makers, but also technology transfer in the form of Kue Karah makers to improve the quality of Kue Karah products and increase production volumes. In addition, this service program also provides training and assistance in organizational and financial management. Thus this program has a comprehensive, meaningful, complete and sustainable value.
\end{abstract}

Keywords: Kue Karah; Traditional Cake; Risk of Fatigue; Appropriate Technology 


\section{PENDAHULUAN}

Desa Langung merupakan salah satu desa yang terletak di Kecamatan Meureubo Kabupaten Aceh Barat. Desa Langung Memiliki Jumlah Penduduk 1.847 Jiwa. Dengan mata pencaharian terdiri dari nelayan, Petani, Pedagang dan Jasa. Desa Langung merupakan desa pengahasil kue tradisonal (m.bisnisaceh.com).

Berdasarkan data dari Dinas Koperasi, UKM, Perindustrian dan Perdagangan Kabupaten Aceh Barat menujukkan bahwa jumlah pengrajin Kue Tradisional yang ada di Kecamatan Meurebo adalah sebagai berikut; Desa Meureubo berjumlah 6 pengrajin, Desa Langung berjumlah 74 pengrajin, desa Ujong Drien berjumlah 7 pengrajin, Desa Ujong Tanjong berjumlah 1 pengrajin dan Desa Peunaga berjumlah 2 pengrajin (BPS Aceh Barat, 2018).

Berdasarkan data tersebut di atas menunjukkan bahwa Desa Langung merupakan sentral produksi pembuatan Kue Tradisional Khas Aceh (Kue Karah). Hasil FGD dilapangan bahwa di Desa Langung hampir setiap rumah tangga melakukan usaha pembuat kue tradisional yang salah satunya adalah membuat Kue Karah.

Kelompok Usaha Mawar Desa Langung Kecamatan Meureubo Kabupaten Aceh Barat merupakan UMKM yang bergerak dibidang pembuatan kue khas tradisional Aceh. Selain kue karah sebagai produksi utama UMKM ini juga memproduksi kue tradisional yang lain seperti: sepit, bhoi dan bungong kaye. Kelompok Usaha Mawar semakin berkembang seiring dengan meningkatnya jumlah permintaan kue karah. Namun saat ini Kelompok Usaha Mawar belum mampu memenuhi permintaan pasar karena metode produksi masih menggunakan cara tradisonal atau belum menerapkan teknologi.

Memperhatikan keadaan tersebut maka oleh karena itu kami ingin meningkatkan produktivitas UMKM Pembuat Kue Karah melalui kegiatan pengabdian kepada masyarakat dengan menerapkan teknologi tepat guna bagi pembuat kue tradisional aceh (kue karah) di Desa Langung Kecamatan Meureubo Kabupaten Aceh Barat.

\section{Permasalahan}

Berdasarkan hasil observasi di lokasi mitra menunjukkan bahwa proses pembuatan kue karah untuk memproduksi 100 unit kue karah membutuhkan waktu selama 4 jam kerja tanpa henti. Hal ini menunjukkan bahwa volume produksi yang dihasilkan sangat rendah jika dibandingkan dengan waktu yang terpakai. Selain proses pekerjaan pembuatan kue karah yang dilakukan operator harus standby selama 4 jam, operator juga terpapar panas alat produksi dalam waktu yang cukup lama. Hal ini tentu operator dapat mengalami kelelahan dan muskuloskuletal disorder.

Beberapa masalah lain yang dihadapi oleh mitra adalah rendahnya produktivitas produksi kue khas tradisional aceh (kue karah), kualitas produk kue karah yang dihasilkan tidak berstandar, manajemen organisasi usaha yang masih lemah dan penguasaan iptek yang masih tradisional. Oleh Karena itu intervensi teknologi sangat dibutuhkan bagi UMKM Kue Karah. 


\section{Tujuan Kegiatan}

Tujuan kegiatan pengabdian kepada masyarakat ini adalah untuk menerapkan teknologi tepat guna dalam proses pembuatan Kue Karah sehingga dapat meningkatkan produktivitas produksi. Selain itu program pengabdian ini juga bertujuan untuk memberikan pelatihan dan pendampingan manajemen organisasi dan keuangan sehingga sehingga pelaku UMKM Kue Karah memiliki profil perusahaan yang jelas dan manajemen keuangan yang baik sehingga dapat meningkatkan pendapatan UMKM Kue Karah.

\section{METODE PELAKSANAAN}

\section{Waktu dan Lokasi}

Kegiatan pengabdian kepada masyarakat dilaksanakan pada bulan Juni 2019 yang bertempat di Desa Langung Kecamatan Meureubo Kabupaten Aceh Barat Propinsi Aceh.

\section{Metode}

Metode pelaksanaan program kegiatan pengabdian ini berbasis riset melalui langkah-langkah berikut :

1) Sosialisasi Program

Kegiatan ini dilakukan untuk mengenalkan rencana kegiatan pengabdian berbasis riset kepada mitra sehingga mitra dapat memahami dengan baik rencana kegiatan pengabdian tersebut. Sosialisasi ini juga dilakukan untuk memperlancar proses pelaksanaan pengabdian nantinya. Melalui kegiatan sosialisasi ini diharapkan semua kendala dapat diselesaikan agar pelaksanaan program Pengabdian Berbasis Riset berjalan dengan baik dan tepat sasaran.

2) Observasi Lapang

Kegiatan ini dilakukan untuk mencari masukan permasalahan yang ada di usaha mitra maka dilakukan pertemuan dan diskusi dengan ketua dan anggota kelompok mitra UMKM Kue Karah.

3) Pelatihan Manajemen Organisasi Mitra

Pelatihan manajemen ini dilakukan untuk memberikan gambaran tentang cara mengelola suatu usaha yang terdiri dari unit-unit mikro ini harus bisa dikelola secara terorganisir/terstruktur untuk menjaga kualitas dan kontinyuitas sirkulasi sirkulasi bahan baku dan produk.

Perencanaan arah pengembangan usaha kedepan sangat diperlukan pada UMKM Kue Karah. Kegiatan ini juga memberikan gambaran perencanaan dan strategi bagi kelompok mitra dalam mengembangkan usaha dan target yang akan dicapai.

4) Perancangan Dan Pembuatan Alat

Kegiatan ini dilakukan dalam rangka membuat alat pembuat kue Karah yang dapat meningkatkan produktivitas UMKM Kue Karah. Tahapan-tahapan yang dilakukan pada kegiatan ini adalah: 
a. Perancangan Alat Pembuat Kue Karah

Perancangan alat pembuat kue karah dirancang dengan beberapa bagian yaitu :

- Rangka besi digunakan untuk rangka alat pembuat kue karah

- Roda gigi digunakan untuk mengatur dan mengubah perputaran alat dan mentransmisikan daya putaran alat sesuai keinginan.

- Motor dinamo digunakan sebagai sumber tenaga untuk memutar mesin pembuat kue karah

- Gagang wadah sebagai gagang wadah adonan kue karah yang terbuat dari plat besi

- Wadah adonan sebagai tempat meletakkan adonan kue karah terbuat dari plat aluminium

- Rangkaian elektronika sebagai pengatur sistem elektronika pada mesin pembuat kue karah

- Plat besi digunakan sebagai rumah alat pembuat kue karah

- Koil pemanas sebagai alat pemanas minyak untuk pengorengan

- Wajan (Kuali) digunakan sebagai tenpat untuk menggoreng kue karah.

b. Fabrikasi dan Perakitan

Komponen-komponen yang sudah direncanakan untuk membuat alat ini di fabrikasi (dibuat) sesui dengan rancangan alat dan dirakit seperi gambar tersebut di atas sehingga menjadi alat pembuat kue karah sesuai dengan yang sudah direncanakan.

5) Pengujian Alat Pembuat Kue Karah

Pengujian alat dilakukan untuk mengetahui unjuk kerja alat secara keseluruhan apakah komponen alat sudah berfungsi sesuai dengan spesifikasi masingmasing. Pengujian alat ini dilakukan untuk melihat hal-hal sebagai berikut:

a. Kehandalan mekanisme komponen alat

b. Kualitas produk Kue Karah

c. Efesiensi alat

6) Pelatihan Pengoperasian Alat Dan Perawatan Alat

Pelatihan ini bertujuan agar mitra dapat menggunakan alat pembuat kue karah dengan baik dan mampu melakukan perawatan alat agar alat dapat bertahan lama.

7) Monitoring Dan Evaluasi

Kegiatan ini bertujuan untuk melihat apakah alat tersebut berfungsi dengan baik pada proses produksi pembuatan kue karah di mitra. Kegiatan ini juga dilakukan untuk melihat perkembangan mitra setelah menggunakan alat dan mendapat pelatihan manajemen organisasi. Kegiatan ini juga dilakukan untuk melihat dan mengetahui kendala-kendala yang dihadapi oleh mitra setelah dilakukan pengabdian ini. 


\section{HASIL DAN PEMBAHASAN}

\section{Sosialisasi Program}

Kegiatan ini dilakukan untuk mengenalkan rencana kegiatan pengabdian berbasis riset kepada mitra sehingga mitra dapat memahami dengan baik rencana kegiatan pengabdian tersebut. Sosialisasi ini juga dilakukan untuk memperlancar proses pelaksanaan pengabdian nantinya. Melalui kegiatan sosialisasi ini diharapkan semua kendala dapat diselesaikan agar pelaksanaan program Pengabdian Berbasis Riset berjalan dengan baik dan tepat sasaran.

Pada tahapan ini diberikan penjelasan-penjelasan yang berhubungan dengan pelaksanaan program, seperti penyuluhan berkaitan dengan penerapan teknologi tepat guna dalam proses pembuatan kue karah dan melakukan pembinaan manajemen organisasi dan manajemen keuangan.

Pelaksanaan program dilaksanakan sesuai dengan kesepakatan bersama antara tim pengusul, Kelompok Usaha Mawar di Desa Langung Kecamatan Meureubo Kabupaten Aceh Barat. Pada tahapan ini dihadiri oleh Kelompok Usaha Mawar sebanyak 6 (tiga) orang dalam penjelasan ini dilakukan diskusi untuk kelancaran kegiatan baik penyuluhan dan praktek lapang.

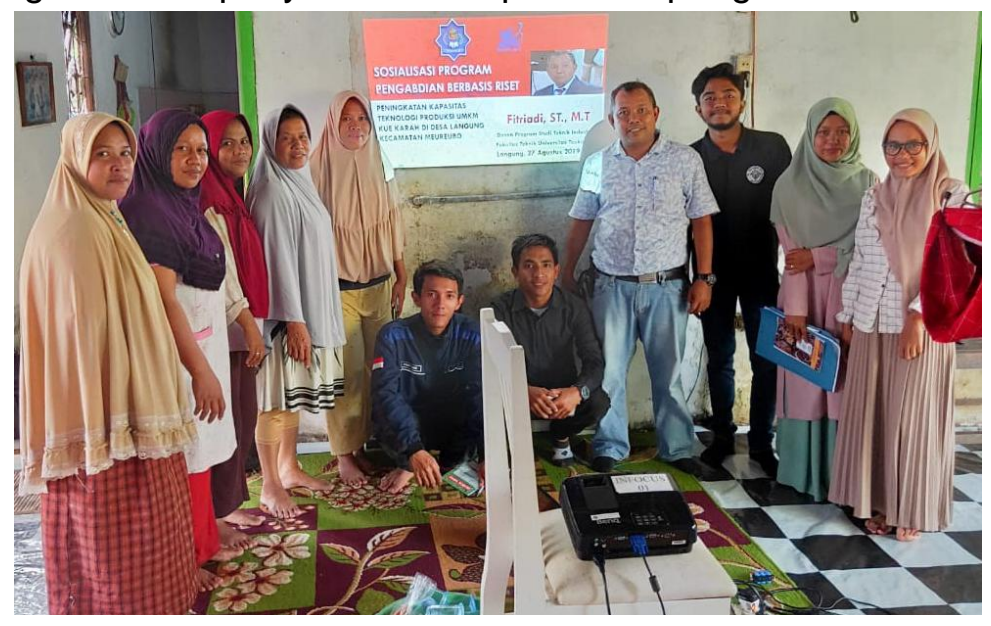

Gambar 1. Sosialisasi Program

\section{Observasi Lapang}

Kegiatan ini dilakukan untuk mencari masukan permasalahan yang ada di usaha mitra maka dilakukan pertemuan dan diskusi dengan ketua dan anggota kelompok mitra UMKM Kue Karah. Observasi lapang ini dilakukan bertujuan untuk mengamati proses produksi pembuatan kue karah, mengamati lingkungan kerja mitra, mengamati manajemen organisasi dan keuangan mitra, mengamati kualitas produk kue karah mitra dan mengamati kondisi pemasaran mitra.

Berdasarkan hasil observasi lapang terhadap lima tujuan tersebut diatas didapatkan hasil sebagai berikut :

1) Proses produksi pembuatan kue karah

Proses produksi pembuatan Kue Karah masih dilakukan dengan cara manual. Proses pembuatan kue karah untuk memproduksi 100 unit kue karah membutuhkan waktu selama 4 jam kerja tanpa henti. Hal ini menunjukkan 
bahwa volum produksi yang dihasilkan sangat rendah jika dibandingkan dengan waktu yang terpakai.

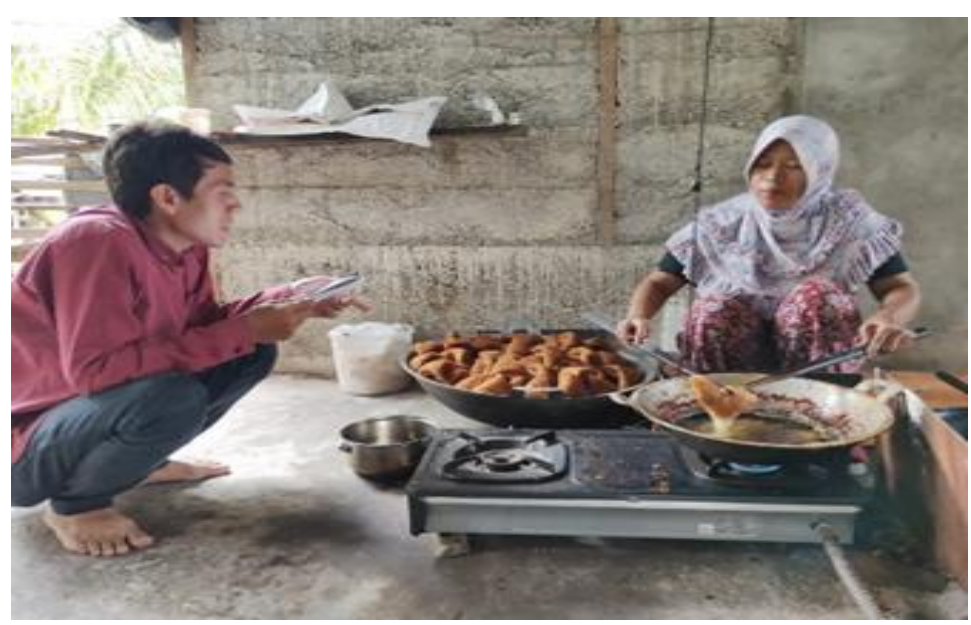

Gambar 2. Proses produksi pembuatan kue karah

2) Lingkungan Kerja Mitra

Selama proses produksi pembuatan kue karah yang secara manual dan tradisional, operator terlihat pada sikap postur kerja yang dilakukan pada posisi duduk jongkok didepan wadah penggorengan, sehingga operator mengalami temperatur suhu badan yang berlebihan akibat lingkungan kerja yang panas, dan juga keluhan pada bagian tangan, lengan, bahu dan pinggang, dikarenakan sikap kerja yang cukup lama dan di lakukan terus-menerus secara berulang lebih kurang 4-5 jam per hari.

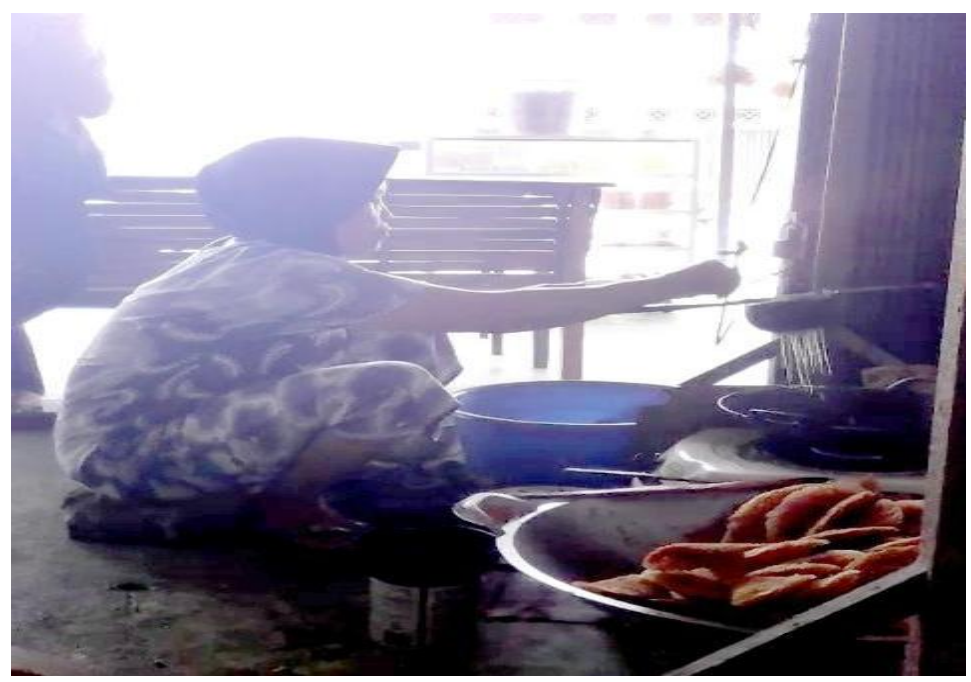

Gambar 3. Lingkungan Kerja Mitra

3) Manajemen Organisasi dan Keuangan Mitra

Manajemen organisasi usaha yang masih lemah karena masih menggunakan manajemen keluarga. 


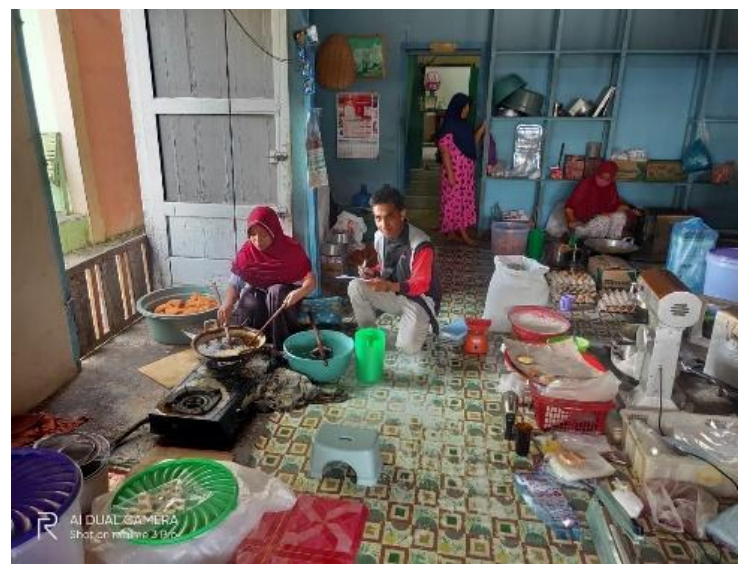

Gambar 4. Manajemen Organisasi dan Keuangan Mitra

4) Kualitas Produk Kue Karah

Kualitas produk kue karah yang dihasilkan tidak standar, baik dari segi ukuran maupun dari segi tingkat kematangan, sehingga hal ini dapat menyebabkan menurunnya pendapatan yang didapat oleh UMKM Kue Karah.

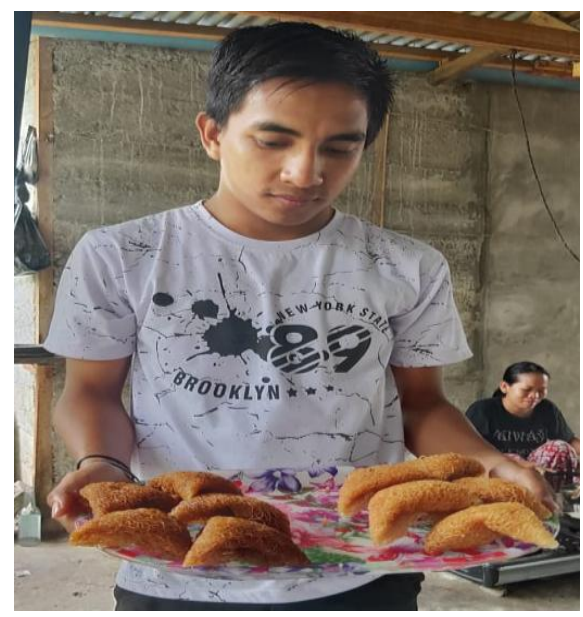

Gambar 5. Kualitas Produk Kue Karah

5) Kondisi Pemasaran Mitra

Metode pemasaran masih dilakukan dengan memasarkan dikios depan rumah (menunggu konsumen) atau menitipkan dikios sekitar.

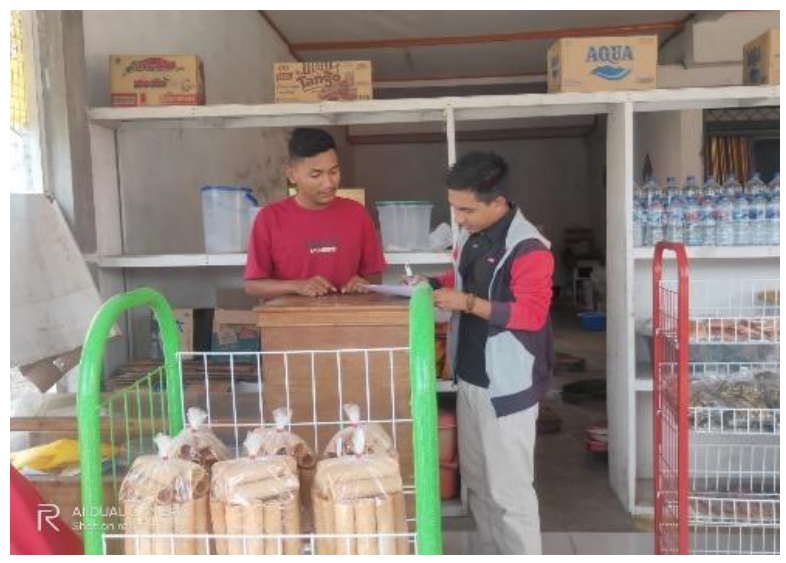

Gambar 6. Kondisi Pemasaran Mitra 


\section{Pelatihan Manajemen Organisasi Mitra}

Pelatihan manajemen ini dilakukan untuk memberikan gambaran tentang Pelatihan manajemen ini dilakukan untuk memberikan gambaran tentang cara mengelola suatu usaha yang terdiri dari unit-unit mikro ini harus bisa dikelola secara terorganisir/terstruktur untuk menjaga kualitas dan kontinyuitas sirkulasi sirkulasi bahan baku dan produk.

Usaha mikro ini juga perlu diarahkan untuk lebih meningkatkan pendapatan dengan mengembangkan usaha dari sisi permodalan. Dengan didapatnya cara meraih modal yang lebih besar diharapkan adanya proses lanjutan agar produk kue karah tersebut mempunyai nilai jual.

Perencanaan arah pengembagan usaha kedepan sangat diperlukan pada UMKM Kue Karah. Kegiatan ini juga memberikan gambaran perencanaan dan strategi bagi kelompok mitra dalam mengembangkan usaha dan target yang akan dicapai.

Pengenalan sistem pembukuan diperlukan untuk menghitung modal, aset, kondisi keuangan (cashflow), dan keuntungan/kerugian yang terjadi. Dengan terdatanya kondisi usaha maka akan mudah dalam merancang manajemen, strategi, dan untuk mendapatkan permodalan bagi UMKM Kue Karah.

Metode yang digunakan dalam pelatihan ini adalah ceramah, diskusi dan Pembimbingan.

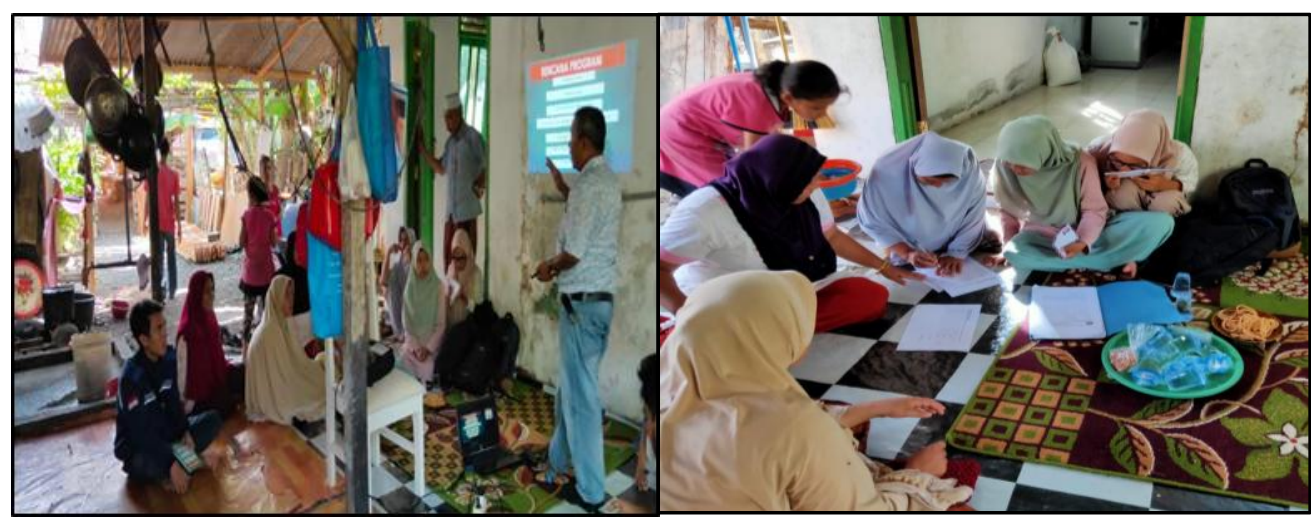

Gambar 7. Dokumentasi kegiatan Pelatihan Manajemen Organisasi dan Pendampingan

\section{Perancangan dan Pembuatan Alat}

Kegiatan ini dilakukan dalam rangka membuat alat pembuat kue Karah yang dapat meningkatkan produktivitas UMKM Kue Karah. Tahapan-tahapan yang dilakukan pada kegiatan ini adalah:

a) Perancangan Alat Pembuat Kue Karah

Perancangan alat pembuat kue karah dirancang seperti gambar berikut ini : 


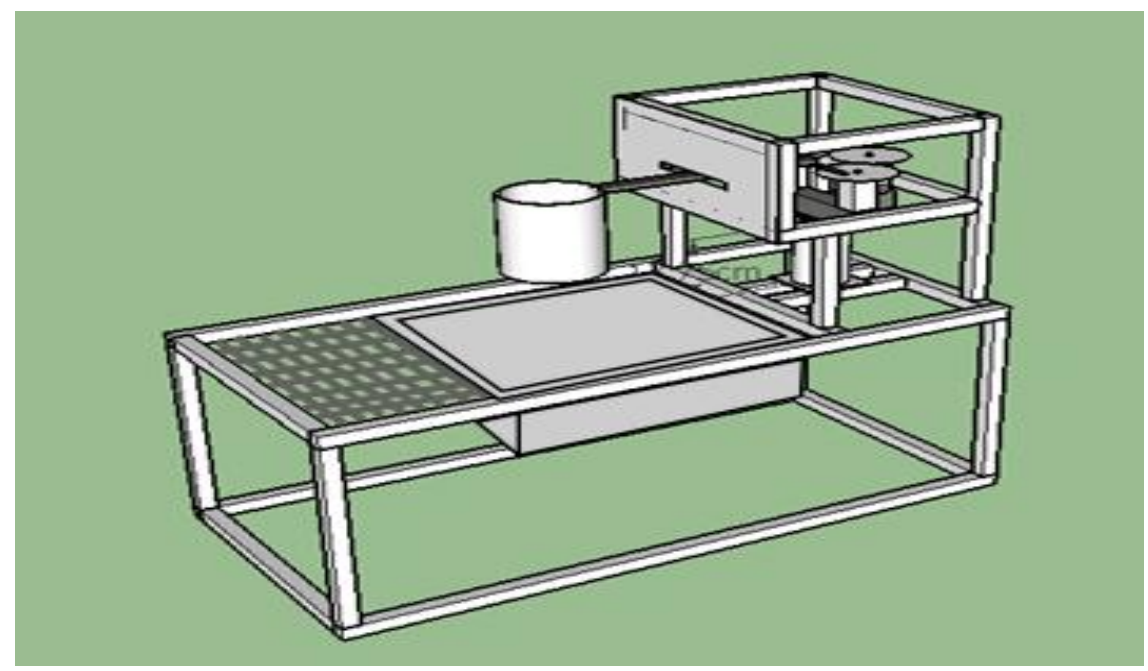

Gambar 8. Rancangan Alat Pembuat Kue Karah

b) Fabrikasi dan Perakitan

Komponen-komponen yang sudah direncanakan untuk membuat alat ini di fabrikasi (dibuat) sesuai dengan rancangan alat dan dirakit seperi gambar $8 \mathrm{di}$ atas sehingga menjadi alat pembuat kue karah sesuai dengan yang sudah direncanakan. Detil fabrikasi dan perakitan pembuatan alat dapat dilihat pada gambar-gambar berikut :

(1) Pengukuran Plat

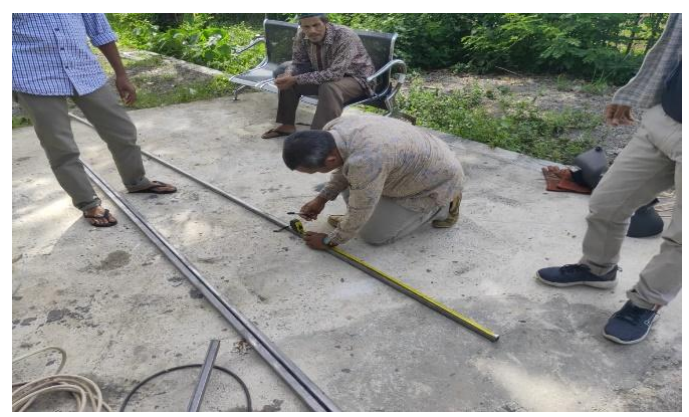

Gambar 9. Pengukuran Plat

(2) Pemotongan Plat

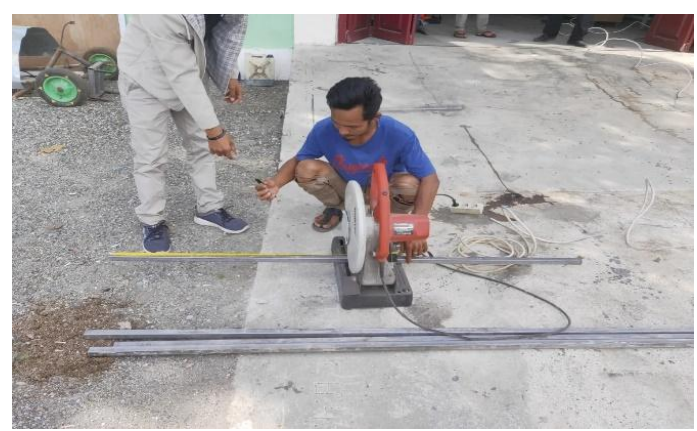

Gambar 10. Pemotongan Plat 
(3) Perakitan Rangka Alat (Pengelasan)

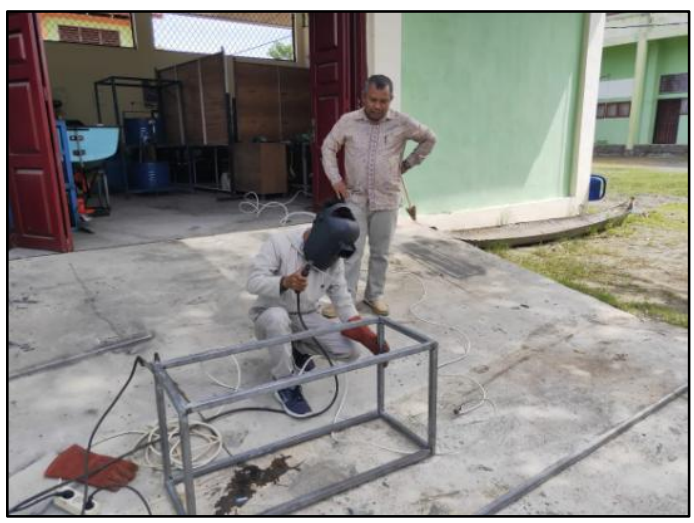

Gambar 11. Perakitan Rangka Alat (Pengelasan)

(4) Pembuatan Papan PCB

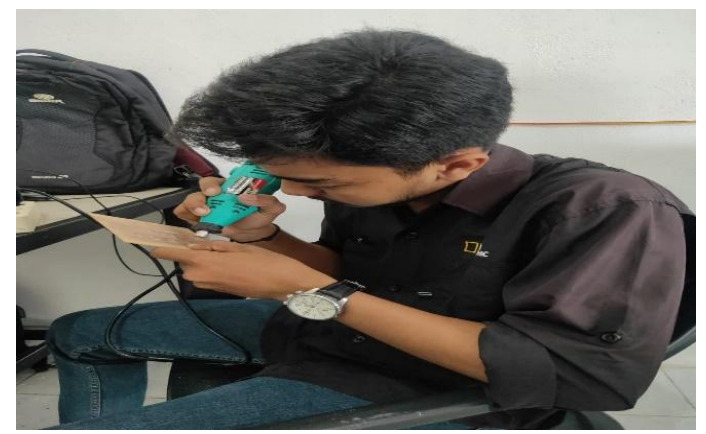

Gambar 12. Pembuatan Papan PCB

(5) Perakitan dan Uji Coba Komponen Elektronik

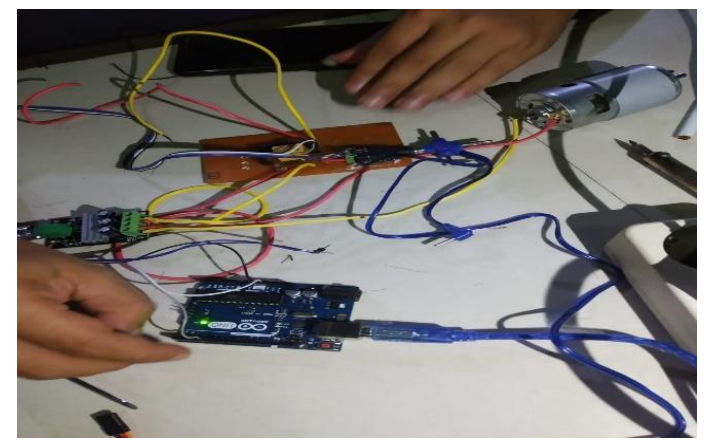

Gambar 12. Perakitan dan Uji Coba Komponen Elektronik 
(6) Perakitan Rangka
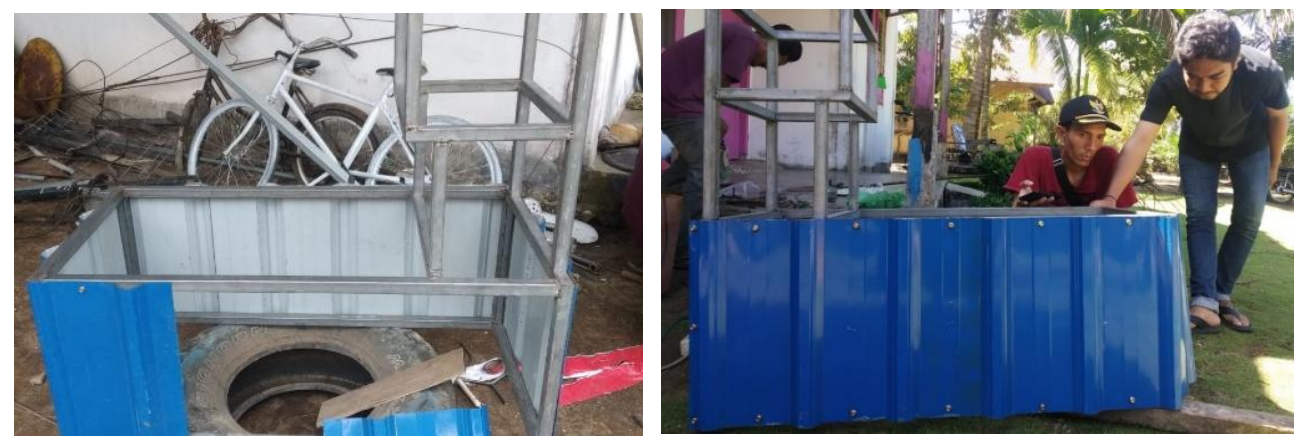

Gambar 13. Perakitan Rangka

(7) Perakitan Mesin

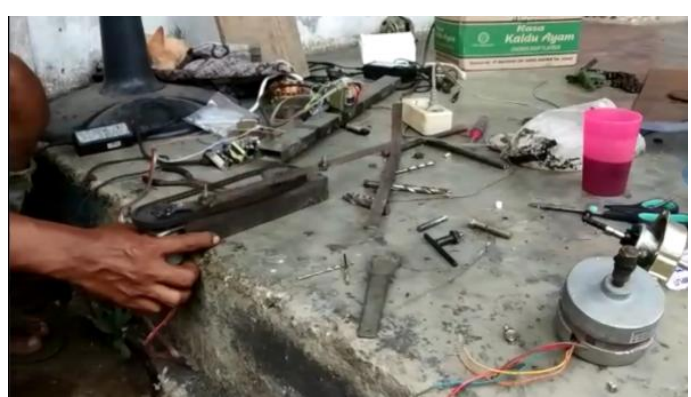

Gambar 14. Perakitan Mesin

(8) Perakitan Rangka Mesin

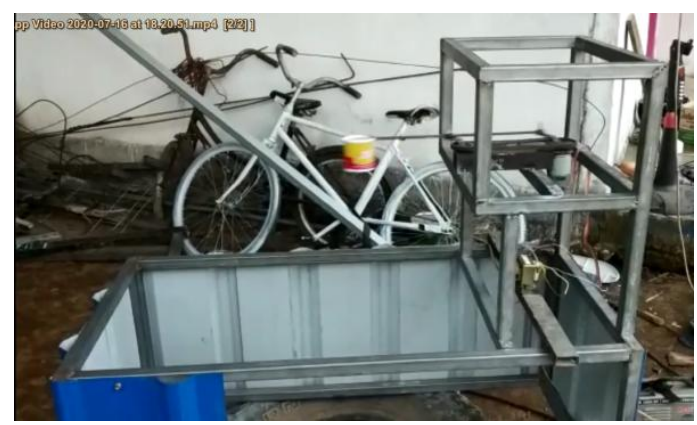

Gambar 15. Perakitan Rangka Mesin

(9) Perakitan Mesin ke Rangka
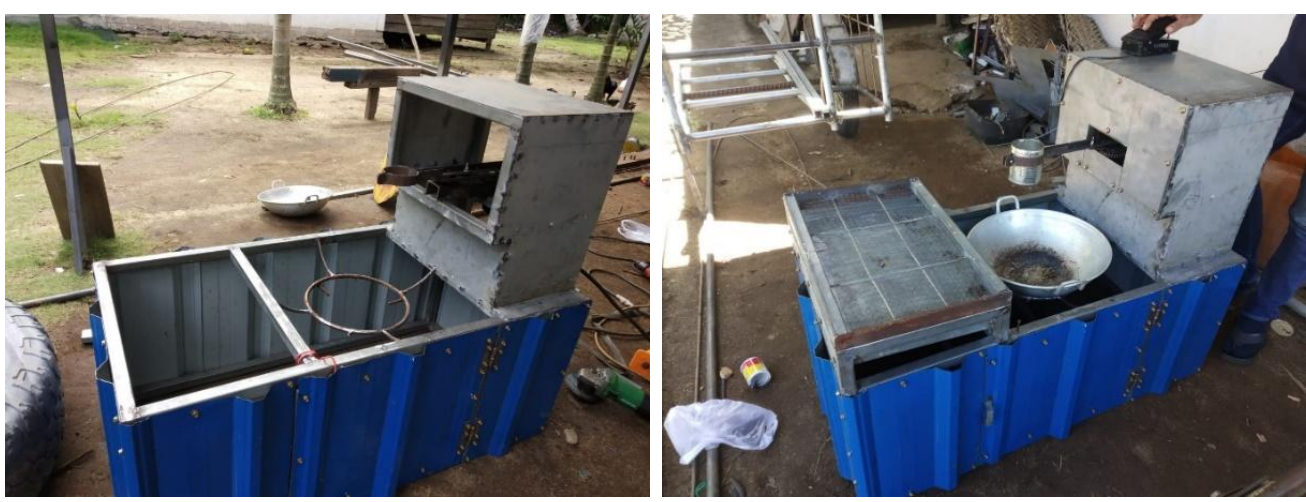

Gambar 16. Perakitan Mesin ke Rangka 


\section{Pengujian Alat Pembuat Kue Karah}

Pengujian alat dilakukan untuk mengetahui unjuk kerja alat secara keseluruhan apakah komponen alat sudah berfungsi sesuai dengan spesifikasi masing-masing.

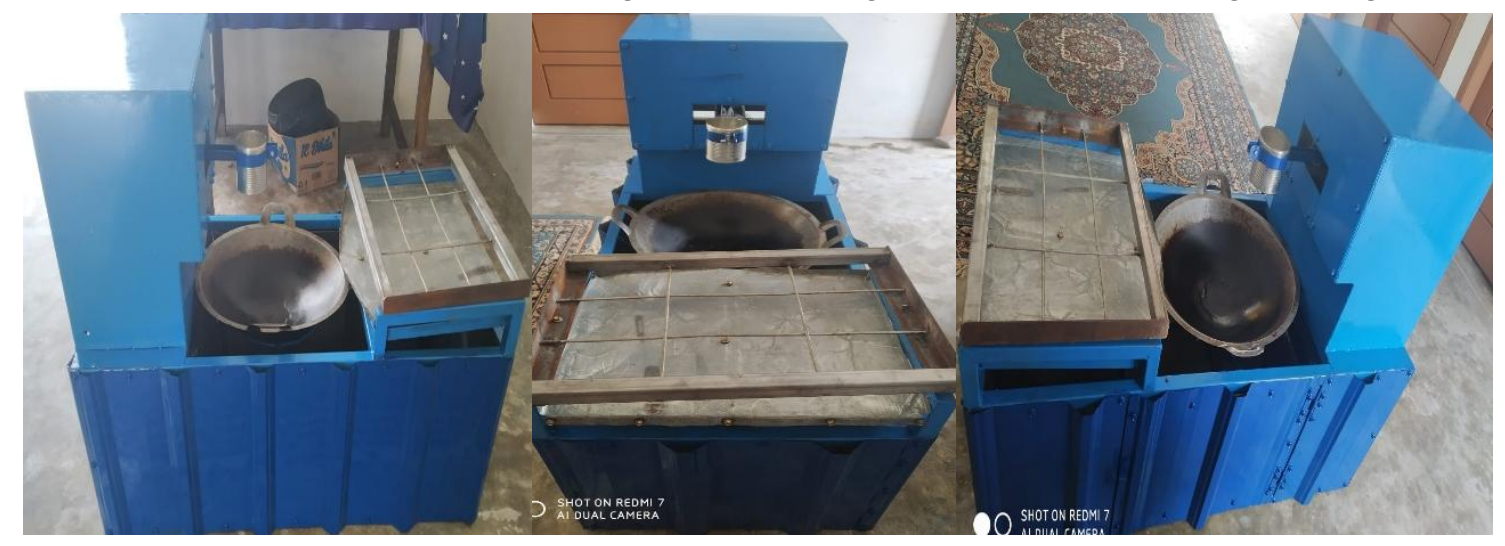

Gambar 17. Proses Pengujian Alat

\section{Pelatihan Pengoperasian Alat dan Perawatan Alat}

Pelatihan ini bertujuan agar mitra dapat menggunakan alat pembuat kue karah dengan baik dan mampu melakukan perawatan alat agar alat dapat bertahan lama.

\section{Monitoring dan Evaluasi}

Kegiatan ini juga dilakukan untuk melihat perkembangan mitra setelah menggunakan alat dan mendapat pelatihan manajemen organisasi. Kegiatan ini juga dilakukan untuk melihat dan mengetahui kendala-kendala yang dihadapi oleh mitra setelah dilakukan pengabdian ini.

\section{SIMPULAN}

Berdasarkan hasil dan pembahasan maka dapat disimpulkan bahwa peningkatan produktivitas produksi Kue Karah kelompok Usaha Mawar Desa Langung dapat dilakukan dengan melakukan peningkatan teknologi tepat guna melalui alat pembuat kue karah hasil dari pengabdian berbasis riset ini.

Pembuatan alat pembuat kue karah dapat dilakukan dengan baik sesuai dengan rencana. Ada peningkatan produktivitas yang signifikan dari alat tersebut yang mampu memproduksi kue karah sekitar 40 unit/jam yang sebelumnya hanya dapat memproduksi 25 unit/jam atau meningkat sebesar $60 \%$. Kualitas hasil produksi kue karah semakin baik dengan melihat ukurannya semakin seragam. Sehingga alat ini dapat mengatasi permasalahan rendahnya produktivitas produksi dan dapat mengatasi permasalahan kualitas produk yang tidak standar.

Peningkatan sumber daya manusia telah dilakukan dengan pelatihan yaitu tentang operasional alat, manajemen dan analisa ekonomi. Dengan pelatihan tersebut, mitra usaha mempunyai pengetahuan untuk mengoperasikan dan mengelola mesin tersebut untuk mempunyai daya saing pada masyarakat.

\section{DAFTAR PUSTAKA}

Amin, I.A.B., 2013. Pengembangan Komoditas Unggulan UMKM Aceh 2012. Bank Indonesia: Banda Aceh. 
BPS. (2018). Produk Domestik Bruto. URL http://www.bps.go.id. 15 Juli 2019)

Dudung, A., 2012, Merancang Produk. PT. Remaja Rosdakarya: Bandung

Irawan A.P., 2017. Perancangan dan Pengembangan Produk Manufaktur. Andi Publisher: Bandung.

Ginting, R., 2007. Sistem Produksi. Graha Ilmu: Yogyakarta.

Ginting, R., 2013. Perancangan Produk. Graha IImu: Yogyakarta.

Ginting, R., 2013. Rancangan Teknik Industri. USU Press: Medan.

Shigley, E. J, Mischke, Charles E. and Budynas, Richard G. 2004. Mechanical Engineering Design, McGraww Hill, Singapore

Ulrich, Karl T ; Eppinger, Steven D. 2001. Perancangan dan Pengembangan Produk. Salemba Teknika: Jakarta. 